\title{
Vascular endothelial growth factor synthesis in the acute phase of experimental and clinical lung injury
}

\author{
B. Maitre, S. Boussat, D. Jean, M. Gouge, L. Brochard, B. Housset, S. Adnot, C. Delclaux
}

Vascular endothelial growth factor synthesis in the acute phase of experimental and clinical lung injury. B. Maitre, S. Boussat, D. Jean, M. Gouge, L. Brochard, B. Housset, S. Adnot, C. Delclaux. (C) ERS Journals Ltd 2001.

ABSTRACT: Vascular endothelial growth factor (VEGF) is a potent angiogenic and endothelial survival factor, which is abundantly expressed in the normal lung. Conceivably, VEGF may be released by numerous cell types found around the airspaces, including alveolar type 2 cells, alveolar macrophages, and polymorphonuclear neutrophils.

Using a bacteria-induced lung injury model in rats, VEGF expression in lung was investigated. Both VEGF protein and VEGF messenger ribonucleic acid (mRNA), 4 and $24 \mathrm{~h}$ after bacterial challenge (Pseudomonas aeruginosa), were decreased compared with sham rats.

VEGF protein was also investigated in bronchoalveolar lavage (BAL) from patients studied within 7 days of acute respiratory distress syndrome (ARDS) onset and in patients without ARDS. VEGF protein levels in BAL were decreased in patients with ARDS versus those without $\left(14.3 \pm 11.1 \mathrm{pg} \cdot \mathrm{mL}^{-1}\right.$ versus $\left.76.8 \pm 51.1 \mathrm{pg} \cdot \mathrm{mL}^{-1}, \mathrm{p}=0.03\right)$.

In aggregate, these findings show that the initial phase of acute lung injury is associated with a decrease in vascular endothelial growth factor in the lung. This downregulation may represent a protective mechanism aimed at limiting endothelial permeability, and may participate in the decrease in capillary number that is observed during early acute respiratory distress syndrome.

Eur Respir J 2001; 18: 100-106.
INSERM Unité 492, Dépt de Physiologie and Services de Réanimation Médicale et Pneumologie, Hôpital Henri-Mondor, Créteil, France.

Correspondence: C. Delclaux, INSERM U492, Faculté de Médecine, 8, rue du Général Sarrail, 94010 Créteil, France. Fax: 33148981777

Keywords: Acute respiratory distress syndrome

animal study

bronchoalveolar lavage

human study

Pseudomonas aeruginosa pneumonia

Received: August 292000

Accepted after revision January 31 2001
The acute respiratory distress syndrome (ARDS) is a clinical and pathophysiological entity characterized by acute, diffuse injury to the alveolar-capillary wall responsible for respiratory failure. Increases in capillary and alveolar permeability result in interstitial and alveolar oedema, respectively. The endothelial permeability increase is thought to involve both neutrophildependent and neutrophil-independent mechanisms [1]. Among factors that can increase endothelial permeability, the vascular endothelial growth factor (VEGF) family has not yet been investigated in ARDS. Three different forms of VEGF are currently known: VEGF-A (or VEGF), VEGF-B and VEGF-C, each form having a different affinity for different membrane receptors: flt-1(or type 1 receptor), fl-k1(or kinase insert domain-containing receptor (KDR) or type 2 receptor), type 3 receptor and neuropilin-1. VEGF is a highly conserved, dimeric, heparin-binding glycoprotein (molecular weight $46 \mathrm{kDa}$ ). At least four different VEGF transcripts resulting from alternate splicing of a single gene have been described in human cells [2]. VEGF 121 and 165 are secreted in soluble form, whereas VEGF 189 and 206 remain cell-surface associated or are primarily deposited in the extracellular matrix. VEGF seems to specifically affect endothelial cell survival, growth and permeability through binding to the high affinity transmembrane tyrosine kinase receptor flk-1, predominantly located on endothelial cells. In the lung, VEGF may be expressed primarily by epithelial cells and macrophages $[3,4]$. Recently, VEGF has also been shown to be synthesized and stored by human polymorphonuclear neutrophils [5, 6]. Although increased capillary wall permeability is the hallmark of ARDS, a decrease in capillary number and volume sets in rapidly, and is a hallmark of subacute and chronic stages of ARDS [7]. A fibroproliferative process characterized by collagen synthesis in the lung, as reflected by elevated levels of procollagen III in pulmonary oedema fluid, begins within the first $24 \mathrm{~h}$ of acute lung injury, concurrently with the acute phase of increased endothelial and epithelial permeability to proteins [8]. Macroscopically, intra-alveolar fibroproliferation (including capillary proliferation) is visible within 7 days [9], indicating that the process probably starts within the first few days of injury.

Since VEGF, besides its increasing endothelial permeability capability, has recently been described as a major survival factor for endothelial cells, the aim of the present study was to evaluate its evolution at the initial phase of ARDS. To explore the potential function of VEGF in acute lung injury, VEGF was evaluated in a previously described animal model of severe acute lung injury [10]. The VEGF concentration in bronchoalveolar lavage (BAL) fluid from patients with severe ARDS at the initial phase of 
respiratory failure (within the first 7 days) was also evaluated comparatively with patients who were receiving mechanical ventilation, but did not have respiratory failure.

\section{Material and methods}

\section{Rat model of acute lung injury}

Male Sprague Dawley rats weighing $\sim 250 \mathrm{~g}$ were used. The rats were housed in air-filtered, temperature-controlled units, and were allowed free access to food and water.

Alveolar instillation of a Pseudomonas aeruginosa inoculum was performed as previously described $[10,11]$. Briefly, the rats were anaesthetized with halothane administration, and the trachea was exposed. A $P$. aeruginosa inoculum (strain $011.4 ; 8 \times 10^{9}$ $P$. aeruginosa $\cdot \mathrm{mL}^{-1}$ ) in sterile physiological saline was instilled into the trachea using a 25-gauge needle, in a dose of $0.5 \mathrm{~mL} \cdot \mathrm{kg}^{-1}$. Sham-treated rats were instilled with $0.5 \mathrm{~mL} \cdot \mathrm{kg}^{-1}$ of sterile physiological saline. Studies were done $4 \mathrm{~h}, 24 \mathrm{~h}$ and 5 days after tracheal instillation of bacteria or saline. The rats were exsanguinated, and the lung and trachea were removed en bloc. The right lung was snap-frozen in liquid nitrogen for ribonucleic acid (RNA) and protein extraction. To preserve tissue architecture, OCT (Tissuetek, Paris, France) diluted 50\% in phosphate buffered saline was instilled in situ into the left lung, which was then snap-frozen in liquid nitrogen for histologic examination.

\section{Patient selection and sample collection}

Mechanically-ventilated patients were prospectively studied in the medical intensive care unit of the Henri Mondor Hospital, Créteil, France. Patients scheduled for imminent BAL to evaluate suspected ventilatorassociated pneumonia were eligible for the study. To avoid potential confounding due to local cell function changes induced by nosocomial pneumonia, patients with nosocomial pneumonia were excluded, based on the results of quantitative culture of BAL fluid and protected plugged catheter [12].

Patients were divided into two groups based on whether or not they had ARDS, defined as bilateral infiltrates on a frontal chest radiograph with a arterial oxygen tension/inspiratory oxygen fraction $\left(\mathrm{Pa}, \mathrm{O}_{2} /\right.$ $\left.F{ }_{1}, \mathrm{O}_{2}\right)$ ratio $<150 \mathrm{mmHg}$, regardless of positive endexpiratory pressure level, and a pulmonary wedge pressure $<18 \mathrm{mmHg}$. Non-ARDS (control) patients were required to have a $P \mathrm{a}, \mathrm{O}_{2} / F \mathrm{I}, \mathrm{O}_{2}$ ratio $>300 \mathrm{mmHg}$ under mechanical ventilation. The study was approved by the Ethics Committee of the hospital. Written informed consent was obtained from the next of kin.

BAL was performed as previously described [12]. Briefly, three $50 \mathrm{~mL}$ aliquots of sterile, pyrogen-free, $0.9 \% \mathrm{NaCl}$ were instilled and recovered using gentle suction. The fluid recovered after the first $50 \mathrm{~mL}$ instillation was discarded. BAL fluid was filtered through moistened coarse gauze to remove mucus. At the same time, $20 \mathrm{~mL}$ of arterial blood was drawn. A small BAL aliquot was used for a total cell count and cytocentrifuge preparations. The total cell count was done manually using a haematocytometer. Cell smears were stained with standard May-Grünwald Giemsa. Differential cell counts were performed by counting 200 cells. BAL was centrifuged at $300 \times g$ for $7 \mathrm{~min}$ immediately after collection. BAL fluid was aliquoted and frozen at $-80^{\circ} \mathrm{C}$ until use.

\section{Urea determination}

Urea concentration was determined by spectrophotometric absorbance at $600 \mathrm{~nm}$ using the Berthelot reaction (Diagnostic Kit, Boehringer, Mannheim, Germany). The volume of epithelial lining fluid (ELF) recovered by BAL was estimated using the following formula with urea as a marker of dilution: ELF volume $(\mathrm{L})=$ (total amount of urea in recovered BAL fluid $(\mathrm{mmol})) /\left(\right.$ plasma urea concentration $\left.\left(\mathrm{mmol} \cdot \mathrm{L}^{-1}\right)\right)[13]$.

\section{Biological assay}

Enzyme-linked immunosorbent assay for vascular endothelial growth factor and transforming growth factor- $\beta 1$. VEGF and transforming growth factor- $\beta 1$ (TGF- $\beta 1$ ) protein levels were quantified in BAL supernatant and serum using a sandwich enzymetric assay with specific antibodies, as recommended by the manufacturer ( $\mathrm{R}$ and $\mathrm{D}$ System, Minneapolis, $\mathrm{MN}$, USA). Activation for TGF- $\beta 1$ detection was made using acidification and neutralization procedures. A $200 \mu \mathrm{L}$ sample was incubated with $50 \mu \mathrm{L}$ of assay diluent for $2 \mathrm{~h}$ at room temperature in a 96-well plate, coated with a monoclonal antibody. After three washings, a polyclonal antibody-horseradish peroxidase conjugate was added. Incubation was for $2 \mathrm{~h}$ at room temperature. After addition of a colour reagent, absorbance was measured at $450 \mathrm{~nm}$ using a Thermo-Max microplate reader (Dynatec Laboratories, El Paso, TX, USA). For standardization, serial dilutions of recombinant human growth factor were assayed during the same run.

Immunoblotting of vascular endothelial growth factor isoforms. Tissue lysates were prepared from rat lung in lysis buffer containing $20 \mathrm{mM}$ hydroxyethyl piperazine ethane sulphonic acid (HEPES), $0.5 \mathrm{mM}$ ethylene glycol tetra-acetic acid (EGTA), $1 \mathrm{mM}$ DTT and $0.32 \mathrm{M}$ sucrose, $\mathrm{pH}$ 7.4. Protein content was determined using the method of Lowry as modified for the Detergent Compatible protein assay (Bio-Rad, Richmond, CA, USA). Samples $\left(30 \mu \mathrm{g} \cdot\right.$ lane $\left.^{-1}\right)$ were subjected to polyacrylamide gel electrophoresis as described by Hossenlopp et al. [14]. Separated peptides were transferred electrophoretically to Immobilon-P membranes (Millipore Corp., Bedford, MA, USA), which were incubated overnight with a blocking solution containing Tris-buffered saline with $0.05 \%$ Tween 20 (TBS-T) and 3\% bovine serum albumin (BSA). VEGF proteins were detected by incubating the membrane with a polyclonal antihuman VEGF antibody (Santa Cruz Laboratories, Santa Cruz, 
CA, USA). The blots were then washed and incubated with peroxidase-conjugated goat antirabbit immunoglobulin-G (IgG) (Dako A/S Co., Glostrup, Denmark). Immune complexes were visualized using the enhance chemiluminescence detection system (Amersham Corp., Buckinghamshire, UK), and membranes were exposed to autoradiography film (Amersham Corp.).

Analysis of messenger ribonucleic acid expression by reverse transcriptase-polymerase chain reaction amplification and Northern blotting. Total RNA was extracted from the lungs according to an improvement to the single-step RNA isolation method developed by Chomczynski and SACCHI [15]. Total RNA was quantified at 260 or $280 \mathrm{~nm}$, and sample integrity was checked using 1.5\% agarose gel electrophoresis. Total RNAs $(2 \mu \mathrm{g})$ were converted to complementary deoxyribonucleic acids (cDNAs) using 5 units of Maloney murine leukaemia virus (MMLV) (Gibco BRL, Life Technologies, France) and $0.5 \mu \mathrm{g}$ oligo deoxythymidine (dT) for $1 \mathrm{~h}$ at $37^{\circ} \mathrm{C}$. Reverse transcriptase (RT)-generated cDNA encoding VEGF-A and $\beta$-actin (used as a control of RNA integrity and as an internal standard) were amplified using polymerase chain reaction (PCR). Amplification of $5 \mu \mathrm{L}$ of cDNA was performed using $0.2 \mathrm{nM}$ sense and antisense VEGF primers and 2.5 units of Taq polymerase. The oligonucleotide primer sequences for VEGF were 5'CCATGAACTTTCTGCTCTCTTG3' (sense) and 5'GGTGAGAGGTCTAGTTCCCGA3' (antisense). ${ }^{32}$ Phosphate-labelled deoxycytidine triphosphate $\left({ }^{32} \mathrm{P}\right.$-dCTP) was added $(0.3 \mu \mathrm{M}$ for each sample). Samples were amplified for 30 PCR cycles. A $5 \mu \mathrm{L}$ aliquot from each PCR reaction was subjected to polyacrylamide gel electrophoresis and visualized by autoradiography. Their authenticity was confirmed by direct nucleotide sequencing. All reverse transcriptasepolymerase chain reaction (RT-PCR) studies were performed at least four times, using lung RNA from different animals.

For Northern blotting, $20 \mu \mathrm{g}$ of RNA were fractionated by electrophoresis on $1 \%$ agarose, 2.2 $\mathrm{M}$ formaldehyde gels and blotted onto nylon membranes (Stratagene, La Jolla, CA, USA). The blots were prehybridized and hybridized to ${ }^{32} \mathrm{P}$ labelled probes, washed, and exposed to film. Relative band intensity was quantified by scanning densitometry using the intensity of a $28 \mathrm{~S}$ ribosomal ribonucleic acid (rRNA) ethidium bromide-stained band as the comparator. The plasmid containing the VEGF165 insert was obtained by subcloning of PCR amplification product, from rat lung cDNA, into a pCRII vector (In Vitrogen, San Diego, CA, USA) and subjected to DNA sequence analysis (Sequenase, US Biochemical Corp., Cleveland, OH, USA). The probe was generated by labelling plasmid inserts with $(\alpha-P) \mathrm{dCTP}$ using random oligonucleotide priming (Amersham Corp.).

\section{Statistical analysis}

All data are expressed as mean \pm SEM. Betweengroup comparisons were done using nonparametric methods, namely the Mann-Whitney U-test or Spearman rank correlation coefficient as appropriate. Significance was defined as $\mathrm{p}<0.05$.

\section{Results}

Vascular endothelial growth factor expression in rat acute lung injury

The 50\% 24-h mortality rate in this animal model attests to the severity of the lung injury. Histological examination of surviving rats demonstrated diffuse alveolar damage, with infiltration of polymorphonuclear neutrophils and presence of oedema (fig. 1).

Expression in the rat lungs of three VEGF
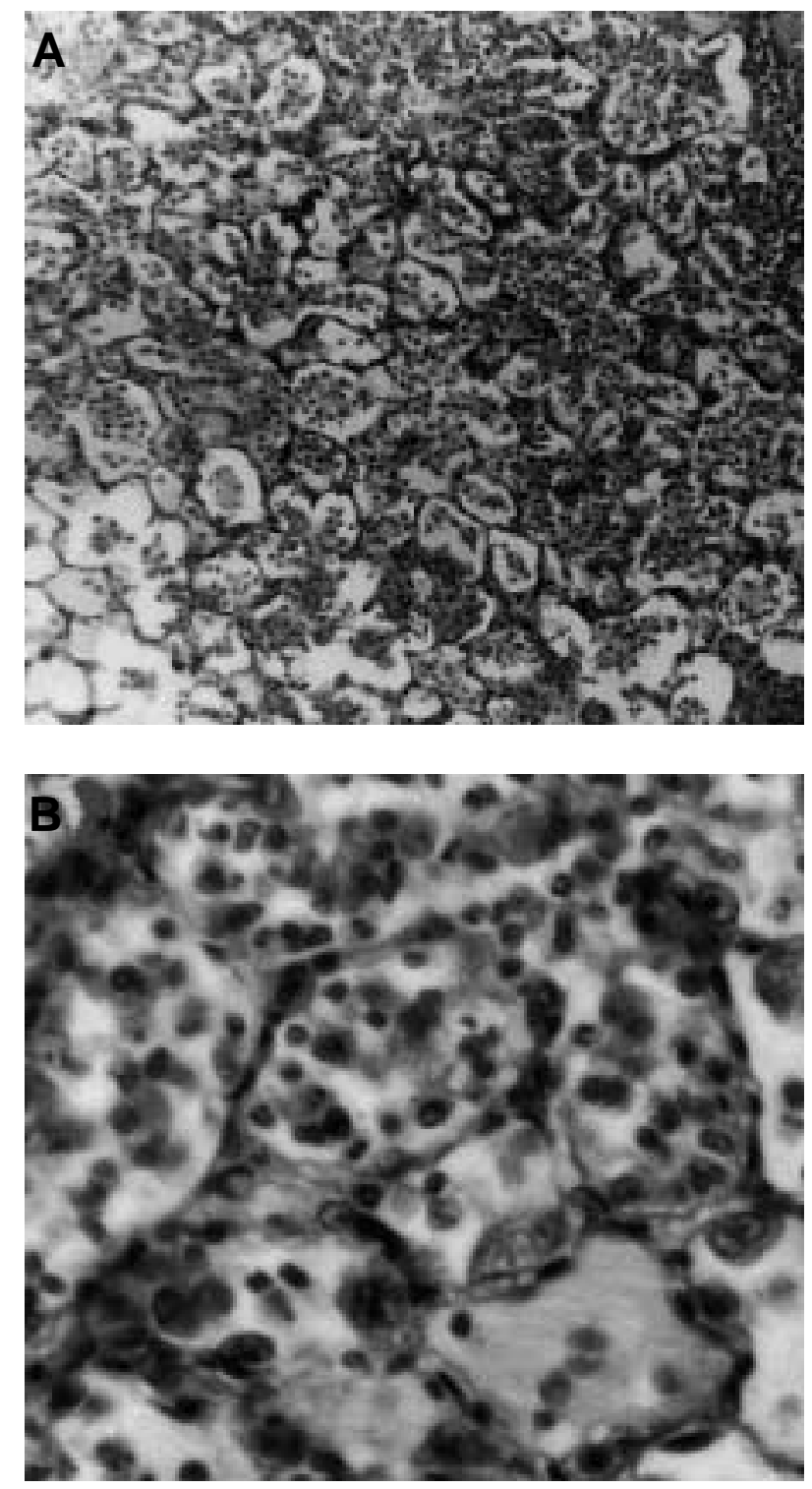

Fig. 1. - Histological section of rat lung: A) original magnification $\times 200$; and $B$ ) original magnification $\times 300,24 \mathrm{~h}$ after intratracheal instillation of Pseudomonas aeruginosa. Alveolar spaces were filled with oedema and inflammatory cells. 


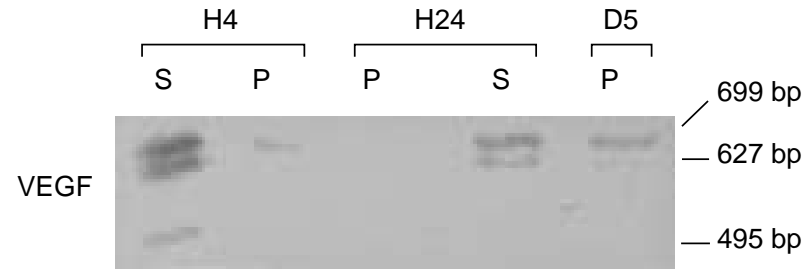

$\beta$-actin

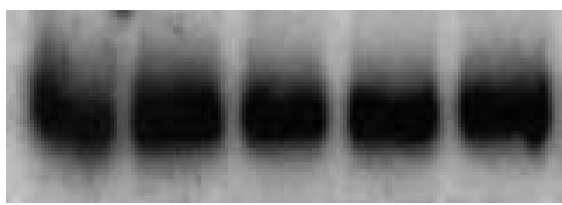

Fig. 2. - Reverse transcriptase-polymerase chain reaction (RTPCR) of vascular endothelial growth factor (VEGF) messenger ribonucleic acid (mRNA) expression in lung of sham (S) and Pseudomonas aeruginosa-instilled rats (PA). Equal amounts of complementary deoxyribonucleic acid (cDNA) were amplified by RT-PCR for VEGF and $\beta$-actin using 30 cycles. PCR products were resolved by $5 \%$ polyacrylamide gel electrophoresis and were analysed by autoradiography. Three different cDNAs were amplified in rat lung corresponding to VEGF 121, 165 and 189. $\beta$-actin was used as a control for mRNA integrity for each sample. bp: base pair.

messenger ribonucleic acid (mRNA) species corresponding to the VEGF 121, 165, and 189 isoforms was evaluated using RT-PCR (fig. 2). No differential expression of VEGF mRNA splice variants were observed during acute lung injury in the model. Northern hybridization of rat lung RNA disclosed a major $3.4 \mathrm{~kb}$ transcript and a faint signal at $1.5 \mathrm{~kb}$. As shown in figure 3 , VEGF mRNA decreased at $4 \mathrm{hr}$, and was further decreased at $24 \mathrm{hr}$. This decrease was reversible: VEGF mRNA levels in survivors five days postinjury were similar to those in sham animals.

Results of immunoblot analysis of VEGF proteins are shown in figure 4. VEGF protein levels were decreased in lung-injured versus sham animals at $4 \mathrm{~h}$ and $24 \mathrm{~h}$. This effect was also reversible, with VEGF protein returning to baseline within 5 days after the injury.

\section{Clinical parameters}

As these results were found in this animal model, an attempt was made to confirm them in patients with ARDS. Nineteen patients were studied and thirteen patients (seven males, six females; mean age, $50 \pm 5 \mathrm{yrs}$ ) had severe ARDS, with a persistently low $P \mathrm{a}, \mathrm{O}_{2} / F \mathrm{I}, \mathrm{O}_{2}$ ratio $(158 \pm 19 \mathrm{mmHg})$ at the time of $\mathrm{BAL}$ $(3 \pm 1$ days after ARDS onset). The cause of ARDS was direct lung injury in seven cases and indirect lung injury in six. Survival rate was 5/13 (38\%). The nonARDS group included six patients without respiratory injury $\left(\mathrm{Pa}, \mathrm{O}_{2} / F \mathrm{I}, \mathrm{O}_{2}\right.$ ratio $>300 \mathrm{mmHg}$ ) (five males, one female; mean age, $59 \pm 5$ yrs). None of the control group patients developed ARDS during the remainder of their intensive care unit stay.

\section{Bronchoalveolar lavage parameters}

ARDS patients had higher ELF volumes than nonARDS patients: $9.9 \pm 2.5 \mathrm{~mL} \cdot 100 \mathrm{~mL}^{-1}$ BAL fluid a)
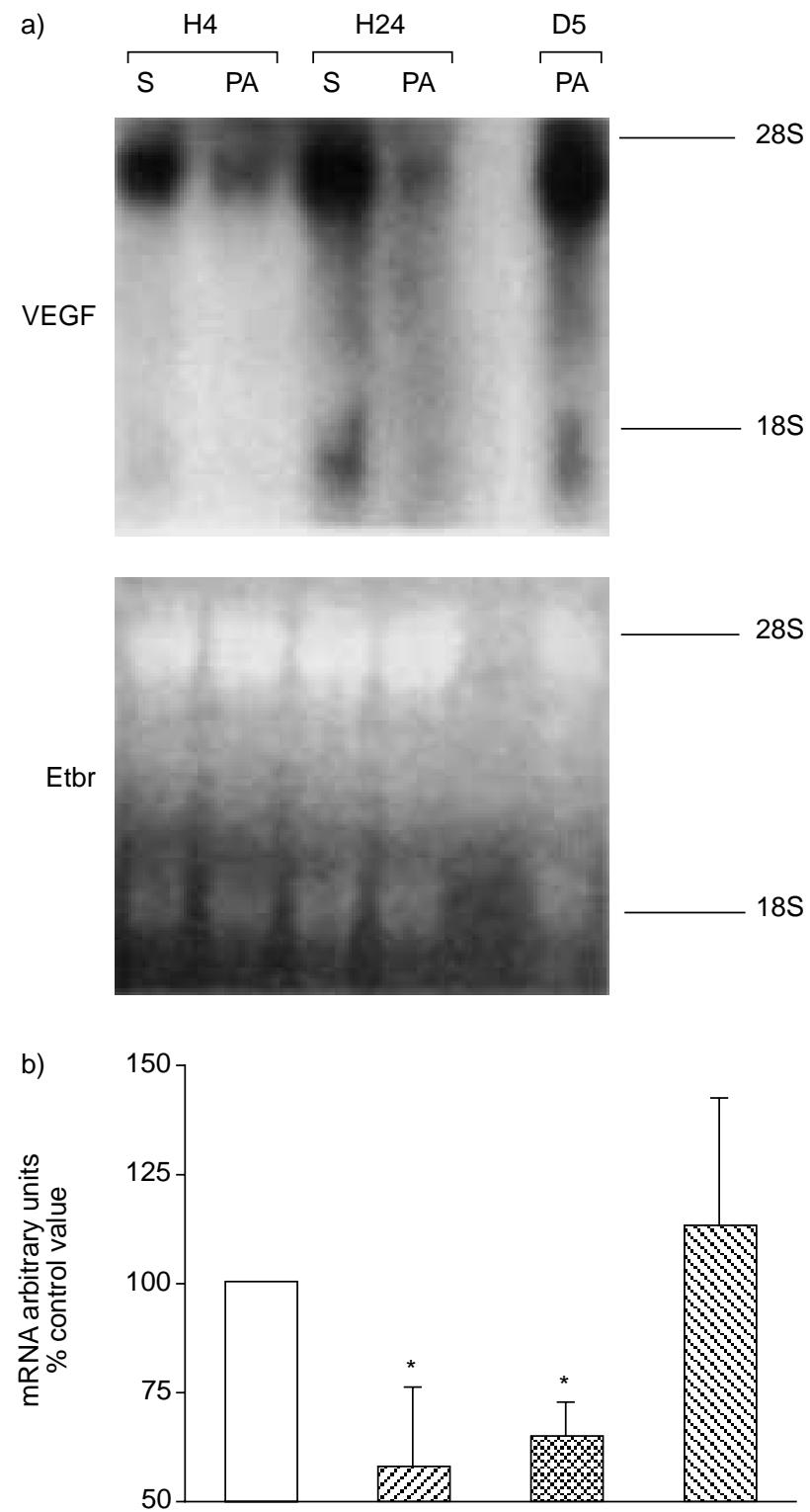

Fig. 3. - Expression of vascular endothelial growth factor messenger ribonucleic acid (mRNA) in rat lung from sham (S) and Pseudomonas aeruginosa-instilled rats (PA). a) Autoradiogram of the hybridization signals with the ethidium bromide (Etbr) staining of the gel on the bottom; and b) histogram showing quantitative representation of vascular endothelial growth factor (VEGF) hybridization obtained from laser densitometric analysis of the exposed films (four independent experiments). Total RNA was extracted from lung of sham $(\square)$ and PA animals $4 \mathrm{~h}(\mathrm{H} 4, \mathbb{Z}), 24 \mathrm{~h}\left(\mathrm{H} 24, \mathrm{x}_{\mathrm{i}}\right)$ and 5 days $(\mathrm{D} 5, \mathbb{\mathbb { }}$ ) after instillation. Expression of VEGF was analysed by Northern blotting using specific human probes, as indicated in Material and methods. *: $\mathrm{p}<0.05$ versus sham condition at the same time (H4 and $\mathrm{H} 24)$.

versus $1.9 \pm 0.6 \mathrm{~mL} \cdot 100 \mathrm{~mL}^{-1}$, respectively $(\mathrm{p}<0.005)$. Total BAL fluid cell count was not significantly increased in mechanically ventilated patients with and without ARDS $\left(430+102 \times 10^{3} \cdot \mathrm{mL}^{-1}\right.$ for ARDS versus $218 \pm 59 \times 10^{3} \cdot \mathrm{mL}^{-1}$ for non-ARDS; $\left.\mathrm{p}=0.07\right)$; however, ARDS patients had a significantly higher percentage of neutrophils in BAL fluid $(63 \pm 7 \%$ of total cell count in ARDS versus $22 \pm 7 \%$ in non-ARDS patients, $\mathrm{p}<0.001)$. 

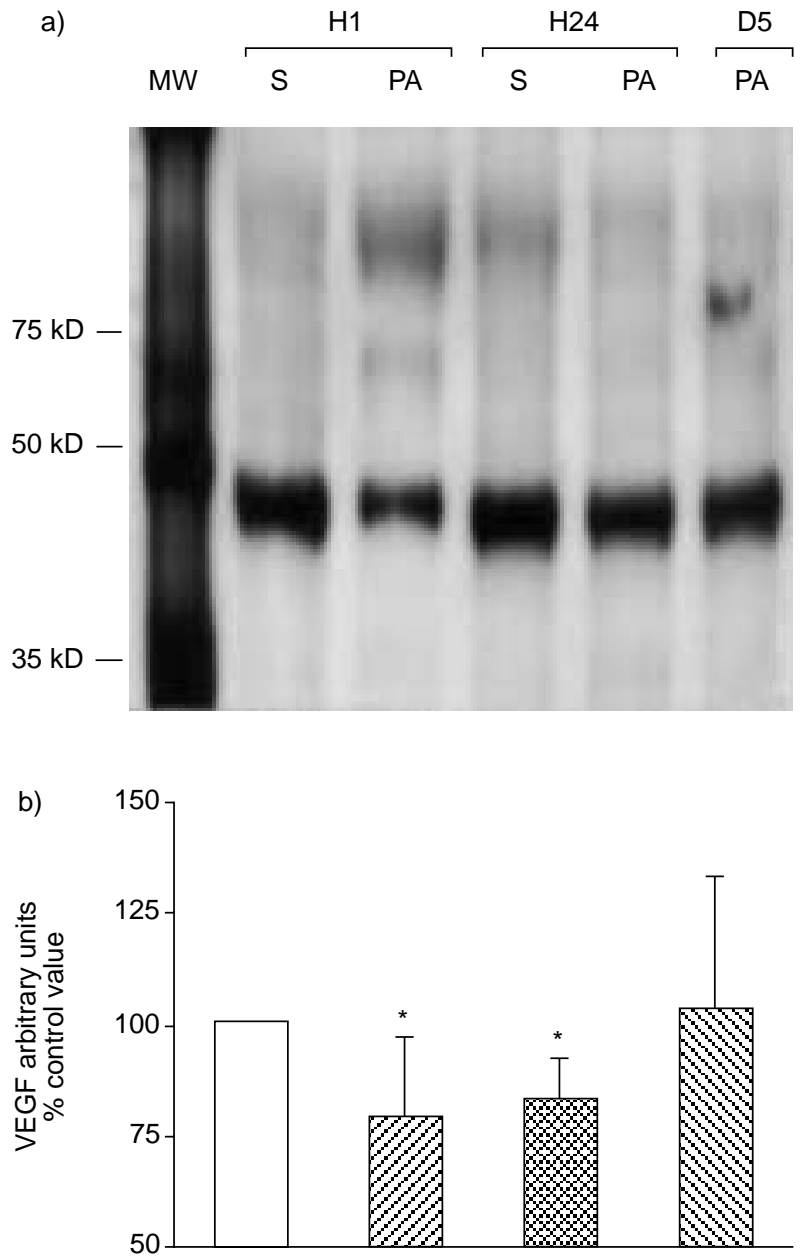

Fig. 4. - Effects of Pseudomonas aeruginosa-induced injury on vascular endothelial growth factor (VEGF) protein levels. a) Autoradiogram of signals for VEGF, showing three bands corresponding to the monomeric form and the dimeric form with or without glycosylation; and b) histogram showing a quantitative representation of VEGF protein levels obtained from laser densitometric analysis of four independent experiments. Results were expressed in arbitrary densitometric units. Cellular proteins were extracted from lung of sham (S, $\square$ ) or Pseudomonas aeruginosa-instilled rats (PA) animals $4 \mathrm{~h}(\mathrm{H} 4, \mathbb{Z}), 24 \mathrm{~h}(\mathrm{H} 24$, 군 $)$ or 5 days $(\mathrm{D} 5, \mathbb{\nabla})$ after instillation. Proteins were analysed by immunoblotting and were fractionated on sodium dodecylsulphate-polyacrylamide gel electrophoresis, transferred to nitrocellulose, and probed with a polyclonal VEGF antibody, as described in Materials and methods. MW: molecular weight markers. *: $\mathrm{p}<0.05$ versus sham condition at the same time ( $\mathrm{H} 4$ and $\mathrm{H} 24)$.

Vascular endothelial growth factor and transforming growth factor- $\beta 1$ levels in bronchoalveolar lavage from patients with and without acute respiratory distress syndrome

VEGF levels in BAL fluid were lower in the 13 ARDS patients than in the six non-ARDS patients $\left(14.3 \pm 11.1 \mathrm{pg} \cdot \mathrm{mL}^{-1}\right.$ versus $76.8 \pm 51.1 \mathrm{pg} \cdot \mathrm{mL}^{-1}, \mathrm{p}=$ $0.03)$ (fig. 5a). As expected, VEGF levels normalized for ELF were significantly decreased in ARDS patients $\left(421 \pm 245 \mathrm{pg} \cdot \mathrm{mL}^{-1}\right.$ versus $5,740 \pm 1,582 \mathrm{pg} \cdot \mathrm{mL}^{-1}$, $\mathrm{p}=0.001)$. Similar results were observed when the mass of VEGF was calculated between the control and the ARDS groups $\left(517 \pm 245 \mathrm{ng} \cdot 100 \mathrm{~mL}^{-1}\right.$ versus
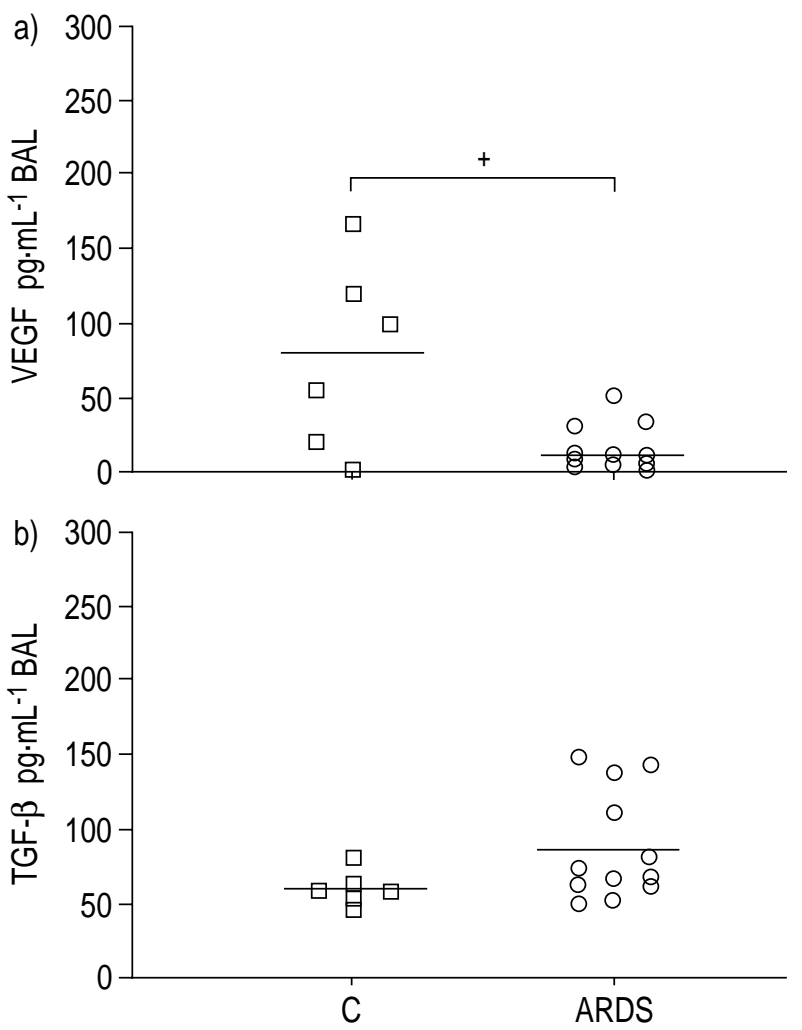

Fig. 5. - a) Vascular endothelial growth factor (VEGF) 165 and b) transforming growth factor- $\beta 1$ (TGF- $\beta 1$ ) levels in bronchoalveolar lavage (BAL) fluid of patients suffering from acute respiratory distress syndrome (ARDS) and of control patients (C). $O$ : cytokine values of individual patients who had BAL sampling at the early phase of ARDS. $\square$ : the individual values obtained in lavage fluids from control patients; - : the geometric means of each group. VEGF and TGF- $\beta 1$ were measured by immunoassay as described in Materials and methods. ${ }^{+}: \mathrm{p}=0.03$ for the comparison between ARDS and control patients.

$5,741 \pm 1,583 \mathrm{ng} \cdot 100 \mathrm{~mL}^{-1}$ of BAL, p<0.001). A trend was observed toward a correlation between VEGF concentration in ELF and the day of BAL procedure during ARDS course $\left(r_{s}=0.10\right)$, but only three patients had a second BAL during their stay. Serum VEGF levels did not differ significantly between ARDS and non-ARDS patients (ARDS: $227 \pm 152 \mathrm{pg} \cdot \mathrm{mL}^{-1}, \mathrm{n}=9$ versus $649 \pm 454 \mathrm{pg} \cdot \mathrm{mL}^{-1}$, $\mathrm{n}=6$, Ns).

In contrast, TGF- $\beta 1$ levels in BAL fluids were slightly elevated in ARDS patients as compared to non-ARDS patients $(85.6 \pm 26.2$ versus $59.2 \pm 6.9$, $\mathrm{p}=0.07$ ) (fig. $5 \mathrm{~b}$ ); interestingly, TGF- $\beta 1$ concentration was reduced when normalized for ELF (ARDS, $1,777 \pm 369 \mathrm{pg} \cdot \mathrm{mL}^{-1}$ versus non-ARDS, 7,667 \pm $\left.3,440 \mathrm{pg} \cdot \mathrm{mL}^{-1} ; \mathrm{p}=0.01\right)$. No correlation was found between VEGF and TGF- $\beta 1$. Neither VEGF nor TGF- $\beta 1$ differed significantly between the direct injury and indirect injury ARDS subgroups.

\section{Discussion}

To investigate lung production of VEGF during acute lung injury (ALI), VEGF protein and mRNA 
were measured in a rat model of severe bacteriainduced ALI previously developed in the laboratory [10]. This model has a $24-\mathrm{h}$ mortality of $50 \%$, and surviving rats exhibit severe hypoxaemia $\left(\mathrm{Pa}, \mathrm{O}_{2} / \mathrm{FI}, \mathrm{O}_{2}\right.$ ratio $\sim 100 \mathrm{mmHg}$ ), marked protein leakage in BAL fluid, increased extravascular lung water, and diffuse alveolar damage $[10,11]$. In the present study, VEGF protein and mRNA were decreased during the initial phase of ALI, at least from the fourth to the 24th hour, compared with control rats. The presented data from a severe rat ALI model are confirmed by the finding that VEGF was reduced in the BAL fluid at the initial phase of lung injury in patients with ARDS. Patients with ARDS were compared to those who were free of pulmonary oedema, but were treated with mechanical ventilation. A significant amount of VEGF protein was detected in BAL fluid from nonARDS patients, without increased alveolar-capillary barrier permeability or lung injury. VEGF levels in ELF were higher than in serum, where platelets may be a major source [16], suggesting local production by the lung and a physiological role for VEGF in the normal lung. VEGF is an angiogenic and permeability increasing factor that is secreted by almost all the cell types found in airspaces or their lining during ARDS, namely alveolar epithelial cells, macrophages, and polymorphonuclear neutrophils. It was speculated that the VEGF present in BAL fluid may have been secreted mainly by alveolar type 2 cells since VEGF immunolocalization and mRNA expression reportedly occurs primarily in this cell type in the normal lung [17, 18], and it could act as a physiological survival factor for endothelial cells via a paracrine effect.

At least two mechanisms may be proposed to explain VEGF downregulation during ALI. Firstly, direct injury of alveolar epithelial cells may lessen the main source of VEGF in the lung by decreasing the number of cells producing VEGF. However, such a mechanism is unlikely since: 1) TUDER et al. [3] reported a decrease in VEGF mRNA after intraperitoneal injection of lipopolysaccharide (LPS) in rats, a model in which epithelial injury does not occur [3]; and 2) the present authors previously demonstrated that alveolar epithelial clearance was stimulated in the bacteria-induced ALI model, suggesting that alveolar type 2 cells are still functional in this model [10]. Secondly, the decrease in VEGF synthesis could constitute a lung response to different kinds of injuries, whether or not they induce epithelial damage. Along this line, acute hyperoxia-induced lung injury, whose charasteristic is endothelial rather than epithelial injury, is also associated with VEGF downregulation [19]. Monocrotalline administration in rats leading to pulmonary hypertension also decreases lung VEGF protein expression [20].

Downregulation of VEGF synthesis by alveolar epithelial cells could have occurred, due to the effect of inflammatory cytokines or cellular proliferation. Most inflammatory cytokines, which are known to be elevated in BAL fluid of ARDS patients [21, 22], stimulate VEGF expression in a variety of cultured cells [23-25] and, consequently, do not explain the decrease in VEGF in BAL fluid of the ARDS patients.
Therefore, TGF- $\beta$ was measured in BAL because this growth factor is known to be one of the most potent inducers of VEGF synthesis by epithelial cells [26]. Although the TGF- $\beta$ levels were higher in BAL fluid in ARDS than in control patients, the TGF- $\beta$ levels in ELF were lower in the ARDS patients. This suggests that the low level of VEGF in ARDS patients may be due to impaired TGF- $\beta$ synthesis. However, a correlation was not found between the level of these two factors. This finding stresses the fact that a moderate variation of any marker has to be interpreted with caution when patients with very different volumes of ELF are compared, even if the method used to measure these volumes has limitations [27].

The finding of a downregulation of a vascular permeability factor, VEGF, was unexpected. The decrease in VEGF may protect lungs from alveolar flooding. In a recent study using an adenovirusmediated gene transfer, KANER et al. [28] have shown that VEGF overexpression induces pulmonary oedema. Since VEGF is a permeability increasing factor, the decreased VEGF production demonstrated in the present study does not exclude its involvement in the early increase of endothelial permeability that may occur concomitantly with extravascular neutrophil migration at the onset of ARDS. Indeed, VEGF is stored in polymorphonuclear leukocyte granules [5, 6] and is probably secreted during neutrophil migration across the endothelium rather than within the airspaces. Moreover, this downregulation could participate in the well-known, but unexplained, decrease in capillary number and volume reported in the earliest histological description of ARDS [7]. It can also be speculated that decreased VEGF expression during the initial phase of ALI may be due to type 2 cell proliferation and may contribute to the initiation of alveolar re-epithelialization. The fibroproliferative response seen in ARDS has been shown to occur within a few days of the injury [29], and recent studies have found elevated levels of two growth factors for alveolar type 2 cells: hepatocyte growth factor and transforming growth factor- $\alpha$ in BAL fluid from patients with ARDS [30, 31]. These results point out the potential importance of epithelial factors in the early phase of ALI.

In conclusion, the vascular endothelial growth factor protein decrease in a rat model of severe acute lung injury was confirmed by findings from bronchoalveolar lavage fluids of patients with early acute respiratory distress syndrome. It is speculated that alveolar vascular endothelial growth factor downregulation may protect the lungs from alveolar flooding, participate in the decrease in capillary number, and contribute to the initiation of alveolar re-epithelialization.

\section{References}

1. Pittet JF, Mackersie RC, Martin TR, Matthay MA. Biological markers of acute lung injury: Prognostic and pathogenic significance. Am J Respir Crit Care Med 1997; 155: 1187-1205.

2. Houck KA, Ferrara N, Winer J, Cachianes G, Li B, 
Leung DW. The vascular endothelial growth factor family: identification of a fourth molecular species and characterization of alternative splicing of RNA. $\mathrm{Mol}$ Endoc 1991; 5: 1806 - 1814.

3. Tuder RM, Flook BE, Voelkel NF. Increased gene expression for VEGF and the VEGF receptors $K D R /$ Flk and Flt in lungs exposed to acute or to chronic hypoxia. Modulation of gene expression by nitric oxide. J Clin Invest 1995; 95: 1798-1807.

4. Maniscalco WM, Watkins RH, Finkelstein JN, Campbell MH. Vascular endothelial growth factor mRNA increases in alveolar epithelial cells during recovery from oxygen injury. Am J Respir Cell Mol Biol 1995; 13: 377-386.

5. Gaudry $M$, Brégerie $O$, Andrieu $V$, El Benna $J$, Pocidalo MA, Hakim J. Intracellular pool of vascular endothelial growth factor in human neutrophils. Blood 1997; 90: $4153-4161$.

6. Taichman NS, Young S, Cruchley AT, Taylor P, Paleolog E. Human neutrophils secrete vascular endothelial growth factor. J Leukoc Biol 1997; 62: $397-400$.

7. Bachofen M, Weibel E. Alteration of the gas exchange apparatus in adult respiratory insufficiency associated with septicemia. Am Rev Respir Dis 1977; 116: 589 594.

8. Chesnutt AN, Matthay MA, Tibayan FA, Clark JG. Early detection of type III procollagen peptide in acute lung injury. Pathogenetic and pronostic significance. Am J Respir Crit Care Med 1997; 156: $840-$ 845.

9. Meduri GU. The role of the host defence response in the progression and outcome of ARDS: pathophysiological correlations and response to glucocorticoid treatment. Eur Respir J 1996; 9: 2650 - 2670.

10. Rezaiguia S, Garat C, Delclaux C, et al. Acute bacterial pneumonia in rats increases alveolar epithelial fluid clearance by a tumor necrosis factor-alpha dependent mechanism. J Clin Invest 1997; 99: $325-$ 335.

11. Delclaux C, Rezaiguia-Delclaux S, Delacourt C, BrunBuisson C, Lafuma C, Harf A. Alveolar neutrophils in endotoxin-induced and bacteria-induced acute lung injury in rats. Am J Physiol 1997; 273: L104-L112.

12. Delclaux C, d'Ortho MP, Delacourt C, et al. Gelatinases in epithelial lining fluid of patients with adult respiratory distress syndrome. Am J Physiol 1997; 272: L442 - L451.

13. Rennard SI, Basset G, Lecossier D, et al. Estimation of volume of epithelial lining fluid recovered by lavage using urea as marker of dilution. J Appl Physiol 1986; 60: $532-538$.

14. Hossenlopp P, Segovia LC, Roghani M, Bredon M, Binoux M. Evidence of enzymatic degradation of insulin-like growth factor-binding proteins in the $150 \mathrm{Kd}$ complex during pregnancy. J Clin Endocrinol Metab 1990; 71: 797-805.

15. Chomczynski P, Sacchi N. Single step method of RNA isolation by acid guanidinium thiocyanatephenol-chloroform extraction. Anal Biochem 1987; 162: $156-159$.

16. Mohle R, Green D, Malcolm A, Moore S, Nachman $\mathrm{RL}$, Rafii S. Constitutive production and thrombininduced release of vascular endothelial growth factor by human megakaryocytes and platelets. Medical Sciences 1997; 94: 663-668.
17. Monacci W, Merrill M, Olfield E. Expression of vascular permeability factor/vascular endothelial growth factor in normal rat tissues. Am $J$ Physiol 1993; 264: C995-C1002.

18. Shifren JL, Doldi N, Ferrara N, Mesiano S, Jaffe RB. In the human fetus, vascular endothelial growth factor is expressed in epithelial cells and myocytes, but not vascular endothelium implications for mode of action. J Clin Endocrinol Metab 1994; 79: 316-322.

19. Maniscalco WM, Watkins RH, D'Angio CT, Ryan RM. Hyperoxic injury decreases alveolar epithelial cell expression of vascular endothelial growth factor in neonatal rabbit Lung. Am J Respir Cell Mol Biol 1997; 16: $557-567$.

20. Partovian C, Adnot S, Eddahibi S, et al. Heart and lung VEGF mRNA expression in rats with monocrotaline- or hypoxia-induced pulmonary hypertension. Am J Physiol 1998; 275: H1948-H1956.

21. Meduri GU, Kohler G, Headley S, Tolley E, Stentz F, Postlethwaite A. Inflammatory cytokines in the BAL of patients with ARDS. Persistent elevation over time predicts poor outcome. Chest 1995; 108: 1303-1314.

22. Suter PM, Suter S, Girardin E, Roux-Lombard P, Grau GE, Dayer J-M. High bronchoalveolar levels of tumor necrosis factor and its inhibitors, interleukin-1, interferon, and elastase, in patients with adult respiratory distress syndrome after trauma, shock, or sepsis. Am Rev Respir Dis 1992; 145: 1016-1022.

23. Cohen T, Nahari D, Cerem LW, Neufeld G, Levi BZ. Interleukin 6 induces the expression of vascular endothelial growth factor. J Biol Chem 1996; 271: $736-741$.

24. Yoshida $\mathrm{S}$, Ono $\mathrm{M}$, Shono $\mathrm{T}$, et al. Involvement of interleukin-8, vascular endothelial growth factor, and basic fibroblast growth factor in tumor necrosis factor alpha-dependent angiogenesis. Mol Cell Biol 1997; 17: 4015-4023.

25. Li J, Perrella MA, Tsai JC, et al. Induction of vascular endothelial growth factor gene expression by interleukin-1 beta in rat aortic smooth muscle cells. $J$ Biol Chem 1995; 270: 308 -312.

26. Pertovaara L, Kaipainen A, Mustonen $\mathrm{T}$, et al. Vascular endothelial growth factor is induced in response to transforming growth factor-beta in fibroblastic and epithelial cells. J Biol Chem 1994; 269: $6271-6274$.

27. Haslam PL, Baughman RP. Report of ERS Task Force: guidelines for measurement of acellular components and standardization of BAL. Eur Respir $J$ 1999; 14: 245-248.

28. Kaner RJ, Ladetto JV, Singh R, Fukuda N, Matthay MA, Crystal RG. Lung overexpression of the vascular endothelial growth factor gene induces pulmonary edema. Am J Respir Cell Mol Biol 2000; 22: 657-664.

29. Ware L, Matthay M. The acute respiratory distress syndrome. $N$ Engl J Med 2000; 342: 1334-1349.

30. Verghese GM, McCormick-Shannon K, Mason RJ, Matthay MA. Hepatocyte growth factor and keratinocyte growth factor in the pulmonary edema fluid of patients with acute lung injury. Am J Respir Crit Care Med 1998; 158: 386-394.

31. Madtes DK, Rubenfeld G, Klima LD, et al. Elevated transformating growth factor-a levels in bronchoalveolar lavage fluid of patients with acute respiratory distress syndrome. Am J Respir Crit Care Med 1998; 158: $424-430$. 